\title{
STATE TAXATION: TENNESSEE LIMITS GHARITABLE PROPERTY TAX EXEMPTION
}

T radrtronally, religious, charitable and educational institutions have received significant state tax exemptions. The courts, favorably inclined toward such institutions, have utilized liberal tests and distinctions in order to broaden the scope of these exemptions. Despite this modern trend toward generous tax treatment of charities, the Tennessee Supreme Court in Nashville v. State Bd. of Equalization ${ }^{1}$ significantly narrowed the scope of Tennessee's exemption statute, after re-examining state exemption policies in the light of present municipal needs, and rejecting previously acceptable judicial distinctions.

The City of Nashville sought to apply its ad valorem property tax to employee cafeteria, snack bar and parking facilities maintained by a religious publications affiliate of the Baptist Church. The State Board of Equalization found that any secular use of the property beneficial to the employees was merely incidental to its primary use for religious purposes, and therefore, the Tennessee statutory requirement ${ }^{2}$ that exempt property be exclusively used for purposes enumerated in its charter was satisfied. The Tennessee Supreme Court reversed on the ground that the present statute did not recognize any such two-purpose use but limited exemption to property exclusively, directly, and solely used for the organization's charter purposes. Concluding that the employee eating and parking facilities were not directly used for religious purposes, the court asserted that the most recent version of the Tennessee exemption statute reflected a legislative policy of tightening charitable exemptions, ${ }^{3}$ and therefore the line of Tennessee cases decided under former statutes which indicated that the exemption was valid was inapplicable.4

I 360 S.W.2d 458 (Tenn. 1962).

2 TEnn. Code Ann. $\$ 67-502$ (2) (1955).

s The court was impressed by the fact that the 1907 statute, which required exclusive use and ownership only, was expressly repealed by the 1935 statute which required ownership, exclusive use and occupation. The court felt that such an express repeal was an expression of a legislative intent to abandon the liberal interpretation applied to the 1907 statute. 360 S.W.2d at 465.

E.g., Vanderbilt Univ. v. Cheney, 116 Tenn. 259, 94 S.W. 90 (1905) (university owned apartments rented to tenants unconnected with the school); M.E. Church, South v. Hinton, 92 Tenn. 188, 21 S.W. 321 (1893) (church publishing house competing with 
'Moreover, the established distinction between primary and incidental use was discarded in favor of a new standard which seems to limit the availability of charitable exemptions in Tennessee.5

Because charitable institutions are often property rich, their exemption from ad valorem property taxation is most important and presents pressing problems. ${ }^{6}$ The major problem stems from state legislatures' persistent liberalization of these charitable exemptions despite municipalities' increased dependence upon the broad tax base brought on by their assumptions of a wider spectrum of services. ${ }^{7}$ While this liberalization results in part from pressures by charitable organizations, it also emanates from the state legislatures' abandonment of property taxation as a source of state revenue $^{8}$ and its use of exemptions as a means of imposing state policies on charitable organizations. ${ }^{9}$ Even where legislatures have drawn strict exemption statutes, another liberalizing factor has arisen through the development of judicial tests and distinctions which compromise the strictest statutes. ${ }^{10}$ Often these distinctions are

secular businesses); State v. Fisk Univ., 87 Tenn. 233, 10 S.W. 284 (1889) (lot used to raise vegetables for school cafeteria).

" "[The act] . . . exempts only property 'occupied" and 'used exclusively' by the institution for a purpose within its charter-property physically used in the work of the institution'; . . . the Act refers to the direct and immediate use of the property itself and not to any indirect and consequential benefit to be derived from its use." 360 S.W.2d at 468. (Emphasis in original.)

- Note, 64 HARv. L. REv. 288 (1950). See generally Aull, The Situation and Outlook For Property Taxation In the South, 12 NAT'L TAX J. 86 (1959); Holbrook \& O'Neill, California Property Tax Trends: 1850-1950, 24 SO. CAL. L. REv. 252 (I951).

${ }^{7}$ See Cheng \& Edwards, Compensatory Property Taxation: An Alternative, 12 Nat'L TAX J. 270 (1959). As an example, in the state of North Carolina, 90.2\% of local taxes during the fiscal year 1959-60 came from the property tax. 1959-60 BIENNIAL. REP. OF N.C. DEPT. OF TAX REsearch 297.

${ }^{8}$ See Newcomer, The Decline of the General Property Tax, 6 NAT'L TAx J. 38, 39 (1953).

- See, e.g., N.Y. TAX LAW $\$ 4(6)$ which states: "No educational corporation or association that holds itself out to the public to be non-sectarian and exempt from taxation pursuant to the provisions of this section shall deny the use of its facilities to any person otherwise qualified, by reason of his race, color or religion."

${ }^{10} \mathrm{See}$, e.g., Church Divinity School v. County of Alameda, I52 Cal. App. 2d 496, 314 P.2d 209 (1957) (student parking lots and faculty residences held incidental and reasonably necessary for school purposes); Bishop v. Treasurer of Arapahoe County, 29 Colo. 143, $68 \mathrm{Pac}$ 272. (1901) (instructor residing in school building-proper and appropriate to charitable purpose); Sunset Memorial Park Ass'n v. Bowers, I73 Ohio St. 358, I82 N.E.2d 318 (1962) (flower shop held incidental to cemetery purposes); Pittsburgh Bible Institute v. Board of Property Assessment, 405 Pa. 297, 175 A.2d 82 (1961) (farm and timber lands integral part of charitable purpose).

Strictness is usually implemented by requiring exclusive use and/or that the property not be used for profit. However, exclusive-use-for-charter-purpose statutes have been "an undisguised invitation to judicial legislation" because it has been difficult to 
foisted upon legislatures and incorporated into later statutes. Added to these factors, there is a paucity of cases testing the exemptions, a result that is either due to a prevailing practice among tax officials not to tax such property, or perhaps to an opinion among these officials that such property is not taxable, since it is generally accepted as being exempt. ${ }^{11}$

State exemption statutes generally fall into three broad categories: those requiring ownership by an exempt organization (ownership statutes); those which disregard title and require only that property be used for exempt purposes (use statutes); and finally, those which require both ownership by an exempt organization and use for exempt purposes (ownership-use statutes). ${ }^{12}$ Those statutes requiring use or ownership-use often specify, as does the Tennessee statute, $^{13}$ that the property must be exclusively used for exempt purposes. Despite the generally accepted rule requiring that exemption statutes be strictly construed against exemption, ${ }^{14}$ the courts in their construction and application have expanded the scope of all three types of statutes. ${ }^{15}$ For example, courts applying use

interpret the line between secular and charitable purposes. Van Alstyne, Tax Exemp. tion of Church Property, 20 OHIO. ST. L.J. 461, 499-500 (1959).

${ }^{21}$ Annot., 75 A.L.R.2d 1106, 1107 n.6 (1961). See generally, Van Alstyne, supra note 10 , at 476 .

${ }^{12}$ E.g., Del. Code ANn. tit. 9, $\$ 8103$ (1953) (ownership statute) applied in St. Stanislaus Kostka Church v. Mayor of Wilmington, 48 Del. 411, 105 A.2d 596 (1954), aff'd, 49 Del. 15, 108 A.2d 581 (1954); ILl. ANN. STAT. ch. 120, $\$ 500$ (Smith-Hurd Supp. 1961) (use statute) applied in First Nat'l Bank v. Ryan, 23 Ill. 2d 250, 177 N.E.2d 854 (1961); N.C. GEN. STAT. \$105-296 (Supp. 1961) (ownership-use statute) applied in Southeastern Seminary, Inc. v. Wake County, 251 N.C. 775, 112 S.E.2d 528 (1960). See Annot., 168 A.L.R. 1222, 1226-27 (1947); see generally Van Alstyne, supra note 10 , at 464 .

${ }_{13}$ "The real estate owned by any . . . charitable . . . institution occupied by such institution or its officers exclusively for carrying out there upon one or morë of the purposes for which said institution was created [shall be exempted] . . . ." TENN. CODE ANN. §67-502 (2) (1955).

14 E.g., Princeton Univ. Press v. Borough of Princeton, 35 N.J. 209. $172.1 .2 \mathrm{~d} 420$ (1961); Cleveland Osteopathic Hosp. v. Zangerle, 153 Ohio St. 222, 91 N.E.2d 261 (1950). See 3 Sutilerland, Statutory Construction $\$ 6409$ (3d ed., Horack 1943, Supp. 1962); Note, 49 Colum. L. Rev. 968, 974 (1949).

${ }_{15}$ See, e.g., State v. Second Church of Christ Scientist, 185 Minn. 242, 240 N.W. 532 (1932) (ownership statute); Pace College v. Boyland, 4 N.Y.S.2d 528, 151 N.E.2d 900 (1958) (ownership-use statute); Goldman v. Friars Club, 158 Ohio St. 185, 170 N.E.2d 518 (1952) (use statute).

As an example of such liberalization under an ownership-use statute, sce County of Hanover v. Trustees of Randolph-Macon College, 125 S.E.2d 812 (Va. 1962). Sce also YMCA v. County of Los Angeles, 35 Cal. 2d 760, 767, 221 P.2d 47, 51 (1950) where the court held that "the rule of strict construction generally applicable to tax exemp. tion laws must prevail here, but adherence to such legal principle does not require that the narrowest possible meaning be given to the exempting language if it would 
and ownership-use statutes have sustained liberality by invoking the primary-incidental distinction ${ }^{16}$ and allowing exemption if the non-charter use is secondary to a charter use, or by applying a test of what is reasonable and necessary for the use and occupation of the premises for charter purposes. ${ }^{17}$

Further liberalization has been accomplished in a minority of states by applying a rule that exemptions are to be liberally construed. ${ }^{18}$ This expansion has also been extended to the majority rule states requiring strict construction against exemption by taking cognizance of the rule that revenue acts are to be strictly construed against the taxing authority. ${ }^{19}$ Thus the taxpayer's burden of proving exemption is easily maintained.20 Moreover, even where exemption has ben denied, the courts have honored established

establish too severe a standard and defeat the apparent objective of the law. Rather the construction of the law, though strict, must also be reasonable."

${ }^{10}$ See, e.g., Shaarai Berocho v. City of New York, 61 N.Y. Super. 163, 18 N.Y.S. 792 (1892) (church property used for caretaker's quarters held incidental to worship); Sunset Memorial Park Ass'n v. Bowers, 173 Ohio St. 358, 182 N.E.2d 318 (1962) (flower shop held incidental to cemetery operation). Parking lots have been similarly exempted. See, e.g., Church Divinity School v. County of Alameda, 152 Cal. App. 2d 496, 314 P.2d 209 (1957) (incidental and reasonably necessary standard applied).

${ }^{17}$ See, e.g., Church Divinity School v. County of Alameda, supra note 16 (student parking lots and residences occupied by married faculty and students exempted); State v. Fairview Hosp. Ass'n, 114 N.W.2d 568 (Minn. 1962); Congregation of B'nai Yisroel v. Township of Millburn, 35 N.J. Super. 67, 113 A.2d 182 (1955) (synagogue parking lot).

${ }^{18}$ E.g., State v. Taylor, 262 Ala. 689, 80 So.2d 618 (1955); Gifford Memorial Hosp. v. Town of Randolph, 119 Vt. 66, 118 A.2d 480 (1955). See 3 Sutulerlano, op. cit. supra note $14, \S 6702$.

${ }^{10}$ See, e.g., Julius Rochrs Co. v. Division of Tax App., 16 N.J. 493, 109 A.2d 611 (1954); Borough of Homestead v. Defense Plant Corp., 356 Pa. 500, 52 A.2d 581 (1947). Tennessee is a majority rule state requiring strict interpretation. First Nat'l Bank v: McCanless, 186 Tenn. 1, 2, 207 S.W.2d 1007, 1008-09 (1948); Illiwois Centual Ry. v. Memphis, 21 Tenn. App. 327, 110 S.W.2d 352 (1937). It has been suggested, however, that "much of the legal literature relating to tax exemptions stresses, as the most significant feature of the extensive litigation relating thereto, the dichotomy between strict and liberal interpretation. The cases themselves, howcver, strongly suggest that the specific statutory language in which the exemption is formulated has a far greater influence upon decision than theoretical doctrines of interpretation." Van Alstync, supra note 10, at 504 .

In addition, further liberalization has been accomplished by drawing distinctions between charitable, religious and educational institutions with some given greater exemption than others. See Salt Lake Lodge v. Groesbeck. 40 Iitah 1, 120 Pac. 192 (1911) (educational and charitable).

${ }^{20}$ Thus courts have upheld exemption of employee parking lots and cafeterias, tennis courts, bowling alleys, golf courses, and swimming pools. See, e.g., Cedars of Lebanon Hosp. v. County of Los Angeles, 35 Cal. 2d 729, 221 P.2d 31 (1950); People v. Catholic Bishop, 311 Ill. 11, 142 N.E. 520 (1924); State $\checkmark$. Fairview Hosp. Ass'n, 114 N.W.2d 568 (Minn. 1962); Sisters of Mercy v. Town of Hooksett. 93 N.H. 301, 42 A.2d 222 (1945). 
liberal tests by holding such facilities not reasonably necessary for the enjoyment of the property, or not incidental to the primary use of the property for charter purposes. ${ }^{21}$ Nevertheless, the Nashtville court eschewed such liberalization when it stressed use rather than ownership, rejected the distinction between primary and incidental use, and strictly interpreted the statute despite the Tennessee rule that revenue acts be construed against the taxing authority.2 Furthermore, the decision suggests that uniform taxation will be the rule, and that henceforth the taxpayer will have a heavy burden in proving exemption.

While state courts and legislatures have felt constrained to extend charitable exemptions because of the strong policy assumed to support them, ${ }^{24}$ the commentators have rejected the present validity of the factors which have supported exemption in the past. ${ }^{25}$ The most frequently cited basis for the exemption, and the most assailed, is. that exemptions actually decrease taxation because the exempt institution assumes some of the welfare burden that the government would normally bear. ${ }^{28} \mathrm{~A}$ more basic though less cited reason is that these exemptions are granted to promote morality thus bene-

${ }^{21}$ E.g., Princeton Univ. Press v. Borough of Princeton, 35 N.J. 309, 172 A.2d 420 (1961) (business printing held not incidental to scholastic printery); Second Church of Christ Scientist v. Philadelphia, $398 \mathrm{~Pa} .65,157$ A.2d 54 (1960) (parking lot held not necessary for church under statute incorporating necessary standard).

${ }^{22}$ First Nat'l Bank v. McCanless, 186 Tenn. 1, 2, 207 S.W.2d 1007, 1008.09 (1948); Illinois Cent. Ry. v. Memphis, 21 Tenn. App. 327, 110 S.W.2d 352 (1936).

$2 s 360$ S.W.2d at 468 .

24 For general discussions on the policy behind exemptions, including those reasons not stated in the text, see Louisville v. Presbyterian Orphan's Home Soc'y, 299. Ky. 566, 186 S.W.2d 194 (1945); Cleveland Osteopathic Hosp. v. Zangerle, 153 Ohio St. 222, 91 N.E.2d 261 (1950); YMCA v. Philadelphia, 323 Pa. 401, 187 Atl. 204 (1936); Holbrook \& O'Neill, California Property Tax Trends, 24 So. CAL. L. REv. 252 (1951); Killough, Exemptions to Educational, Philanthropic and Religious Organizations, in Tax Policy League, Tax Exemptions 23 (1939); Note, 64 Harv. L. Rev. 288 (1950); Note, 49 Colum. L. Rev. 968 (1949).

${ }^{25}$ See Holbrook \& O'Neill, supra note 24; Killough, supra note 24; Stimson, The Exemption of Churches From Taxation, 18 TAxes 361 (1940); Note, 64 HaRv. L. Rvv. 288 (1950). Other widely cited reasons for exemption are: exemptions sustain the impetus for private giving; charitable functions are better and more cheaply performed by private agencies rather than by the state and performance by private agencies insures freedom from political controls; and in addition, the states would' be unable to perform religious functions. On the other hand reasons against exemption are: the amount of exemption far exceeds the lessening of the tax burden caused by the charities assuming state burdens; and states are already performing welfare functions, thus it would be cheaper to concentrate these functions in the state.

${ }^{20}$ See Holbrook, Maxwell \& Rourke, Fifield Manor Tax Refunds Cases: True Meaning of "Charity" Under California Welfare Tax Exemption Restated, 35 So. CaL. L. Rrv. 276, 281 (1962); Holbrook \& O'Neill, supra note 24, at 272; Note, 64 HARv. $\mathrm{L}$. RFV. 288 (1950). 
fiting the state. ${ }^{27}$ Moreover, in the area of religious exemptions it is argued that to abolish the exemption would be an interference with the free exercise of religion. ${ }^{28}$ These reasons for exemption are given less credence in the Nashville opinion than are contemporary policy considerations opposed to exemption. In attacking the economic basis of exemption, the court indicated that today government has largely assumed the welfare burdens once borne by exempt organizations; and that such exempt organizations are actually thwarting these welfare programs to a certain extent by depriving the government of needed revenue. ${ }^{29}$ In addition, the court argues that exemptions which were originally granted to aid struggling charitable institutions, are outdated and that such organizations are abusing their privileged status by actually competing with private, tax-paying businesses. ${ }^{30}$ The court concluded by stating that such tax inequalities violate fundamental American concepts of the equality of taxation, which in turn might some day be responsible for the complete abrogation of the favorable tax status enjoyed by the now-exempt institutions. ${ }^{31}$ And in the context of the separation of church and state, the court pointed out that charitable exemptions are often "poorly concealed forms of tax support for organized religion."32 A further argument against the present status of exemptions is that under the current system of property taxation, the property-rich and the property-poor are taxed, and therefore exempted, at the same rates; thus the property-poor charities which might seem to require the most help are not given any special aid by the exemption policy; and in this respect the policy of exemption is a failure on its own terms. ${ }^{33}$

In the Nashville case, the Tennessee court took a significant step toward limiting charitable exemptions in its determination that the standard to be used in application of the exemption would be in keeping with a policy of strictness rather than the usual liberality. The court, refusing to accept the policy factors assumed to support

\footnotetext{
${ }^{27}$ See Holbrook \& O'Neill, supra note 24, at 272; Stimson, supra note 25, at 362-63; Note, 64 HARv. L. REv. 288, 289 (1950).

${ }^{28}$ See Note, Constitutionality of Tax Benefits Accorded Religion, 49 Colum. L. REv. 968 (1949), and cases cited therein at 968 n.2.

20 360 S.W.2d at $468-70$.

${ }^{30}$ See Note, 64 HaRv. L. REv. 288, 298 (1950).

31300 S.W.2d at 470 .

32 Id. at 469 .

${ }^{33}$ Note, 64 Harv. L. REv. 288, 293 (1950).
} 
liberal exemption, arrived at this determination not through a normal use of orthodox legal doctrines, ${ }^{34}$ but through an examination of policy. Although the court based its decision on current policy rather than on the policy attendant at the statute's enactment, and despite the possibility that the judicial test herein enumerated might be subject to future liberalization, a desirable result was reached. In the absence of a reflection of these economic necessities in new legislation tightening and reshaping the charitable exemption, a court sensitive to the wants of its jurisdiction is powerless to do more than recognize current policy and adapt its statutory construction to such policy whenever possible. Such a policy orientated analysis indicates the need for legislative re-examination of the charitable exemption in view of current economic realities.

\footnotetext{
st For another case rejecting such liberalizing distinctions see Cleveland Osteopathic Hosp. v. Zangerle, 153 Ohio St. 222, 225-26, 91 N.E.2d 261, 263 (1950), wherein the court said: "It seems obvious that no single test is dispositive of whether a hospital, for example, is being conducted exclusively as a charitable project. All the facts in each individual case must be assembled and examined in their entirety and the substance of the scheme or plan of operation exhibited thereby will determine whether the institution involved is entitled to have its property freed from taxes."
} 